\title{
Effects of the Aqueous Extract of Cnestis Ferruginea on the Histological Structure of Female Rat Ovary and Uterine Horns
}

\author{
Zougrou N'guessan Ernest, Blahi Adélaïde Nadia, Kouassi Komenan Daouda and Kouakou Koffi \\ Department of Bioscience, University Félix Houphouët-Boigny Abidjan, Côte d'Ivoire, Africa
}

Received: December 18, 2017; Published: January 03, 2018

*Corresponding author: Zougrou N'guessan Ernest, Department of Bioscience, Biology of Reproduction and Endocrinology Laboratory, University Félix Houphouët-Boigny Abidjan, Abidjan, Côte d'Ivoire, Africa; Email: zougrouernest1977@gmail.com

\begin{abstract}
Cnestis ferruginea (Connaraceae) is a plant used in the treatment of several affections including "sterility" and increased fertility. This work aims to show the pharmacological effects of the aqueous extract of Cnestis ferruginea on the ovary and uterine horn of adult female rats. Thirtysix adult female rats were randomized into 2 sets of 18 each and treated for 15 (set I) and 30 days (set II). Each set was then divided equally into three groups. Group 1 (control) was orally administered with distilled water once a day. Group 2 and group 3 were respectively treated with $50\left(\mathrm{AECF}_{50}\right)$ and $100 \mathrm{mg} / \mathrm{kg}\left(\mathrm{AECF}_{100}\right)$ body weight of aqueous extract of $C$. ferruginea orally once a day. 24 hours after the last doses, the rats of each group are sacrificed. The ovary and uterus of each rat are removed and immediately fixed in $10 \%$ formalin for histological study. Cnestis ferruginea induced a significant $(\mathrm{p}<0.05)$ increase in the number of corpus luteum after 15 days of treatment with $\mathrm{AECF}_{100}$. After 30 days of treatment, the number of corpus luteum increased significantly $(\mathrm{p}<0.05)$ with both doses administered. Both doses also induced significant increases $(p<0.05)$ with the two treatment durations, the number of De Graaf follicles. The number of tertiary follicles increased significantly $(\mathrm{p}<0.05)$ with $\mathrm{AECF}_{100}$ after 15 days of treatment. The duration of 30 days allowed recording a significant increase in the number of tertiary follicles with the two doses administered. The other follicles experienced significant increases with AECF100 after 30 days of treatment. For uterine horns, lumen diameters of uterine horns and uterine glands increased significantly $(p<0.05)$ with both doses administered and both durations of treatment. The thickness of the endometrial and the size of the epithelial cells increased significantly $(p<0.05)$ with $_{\text {AECF }}$ pon $_{10}$ after 15 days of treatment. These latter parameters experienced significant increases with both doses administered at the end of 30 days of treatment. In conclusion, $C$. ferruginea stimulates folliculogenesis and induces ovulation in the ovary. On the uterine horn, this plant has estrogenic properties.
\end{abstract}

Keywords: Cnestis ferruginea; Ovary; Uterine horn; Ovulation; Estrogenic

\section{Introduction}

Man has been using medicinal plants to treat diseases for millennia. According to estimates, more than two-thirds of the world's plant species are of medicinal value. WHO estimates that about $80 \%$ of people living in developing countries depend on traditional medicine for their primary health care needs? About 50 to $60 \%$ of pharmaceuticals are of natural origin or are synthesized from natural products [1,2]. However, there are still many plants for which the mode of action, the biological targets and the side effects of the molecules are not yet elucidated. Yet, they are used by a large part of the population to heal themselves. This exposes them to serious and sometimes irreversible damage. It is then necessary to carry out pharmacological research to study the effectiveness of these plants used in traditional medicine. It is in this context that the plant species Cnestis ferruginea (Connaraceae) a plant used in the treatment of several affections including "sterility" and increased fertility according Tra Bi [3] and N'guessan et al. [4], caught our attention in this study. This work aims to show the pharmacological effects of the aqueous extract of Cnestis ferruginea on the ovary and uterine horn of adult female rats.

\section{Materials and Methods}

\section{Plant Material}

Fresh leaves of Cnestis ferruginea were harvested in November in the Region of Nawa, Department of Soubré, precisely in the village named Trawininkro (V8) (Côte d'Ivoire). A sample of this plant has been identified and authenticated by Professor Aké-Assi at the Laboratory of Botany and Plant Biology of Université Félix Houphouët-Boigny.

\section{Preparation of Extract}

Harvested leaves have been rinsed with distilled water, dried in the shade (sheltered from the sun) at an ambient temperature $\left(24 \pm 2{ }^{\circ} \mathrm{C}\right)$. The dried leaves were crushed with a power mill (IKA A10 Labortechnik, Germany) to obtain a powder. The powder 
obtained has been macerated by mixing $50 \mathrm{~g}$ and $1.5 \mathrm{~L}$ of distilled water and stirred for 24 hours by a magnetic stirrer (Janke \& Kuntelika Labortechnik, Germany). After three times filtration on Whatman filter paper number 1 , the filtrate was concentrated in an air circulating oven at $50{ }^{\circ} \mathrm{C}$ until total dryness. The aqueous extract obtained has been stored at $4{ }^{\circ} \mathrm{C}$ in a refrigerator for the experimental studies.

\section{Animal Material}

Adult female rats, (Rattus norvegicus, Muridae), Wistar strain, virgin, weighing between 130-150 g and aged 55-65 days are from the animal facility of ENS (Ecole Normale Suppérieure). These rats have been used for this study of the aqueous extract of $C$. ferruginea. They were raised in stable temperature room $\left(24 \pm 2^{\circ} \mathrm{C}\right)$. In these premises, the photoperiod was 12 hours and $50-55 \%$ humidity. The animals were fed add libitum water, bread, fish, corn and peanuts.

\section{Experimental Design}

Thirty-six adult female rats were randomly distributed into 2 sets of 18 animals each and treated for 15 (set I) and 30 days (set II). Each set was then divided equally into three groups and treated as follows: Group 1 (control) was orally administered with distilled water once a day. Group 2 and group 3 were respectively treated with $50\left(\mathrm{AECF}_{50}\right)$ and $100 \mathrm{mg} / \mathrm{kg}\left(\mathrm{EACF}_{100}\right)$ body weight of aqueous extract of $C$. ferruginea orally once a day. 24 hours after the last doses, the rats of each group are sacrificed. The ovary and uterus of each rat are removed and immediately fixed in 10\% formalin.

\section{Histological Study}

The uterus and ovary harvested and fixed in Formaldehyde $10 \%$ were dehydrated in an ascending grade of (ethanol), cleared in toluene and embedded in paraffin wax. Serial sections of 5 microns thick were obtained using a rotatory microtome (Leica RM2125 RTS, Allemagne). The deparaffinised sections of the organs were stained routinely with Harris haematoxylene and eosin $(\mathrm{H}$ \& E) stain. The analysis of the sections was done using a tri-ocular photonic microscope (Olympus CK41SF, Philippine) connected to a computer. Imaging and image analysis were done using the Videomet software version 8.0.9 (France).

\section{Statistical Analysis}

The data and graphical representation of the data was performed using the Graph Pad Prism 5.01 software (Microsoft, USA). The experimental results were expressed as Mean \pm SEM and data were assessed by the method of analysis of one-way ANOVA followed by Tukey test with least significant test. P value $<0.05$ was considered significant, $\mathrm{P}$ value $<0.01$ considered highly significant and $P$ value $<0.001$ considered very highly significant.

\section{Result}

\section{Effects of the Aqueous Extract of Cnestis ferruginea on Ovarian Organelles}

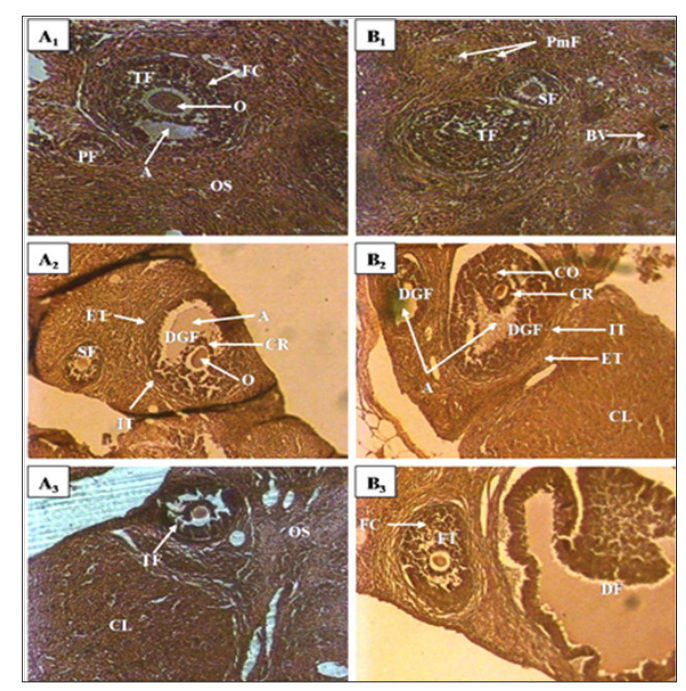

Figure 1: Ovary micrograph of control and treated rats with Cnestis ferruginea at 15 and 30 days

A1: Control (15 days).

A2: Treated $50 \mathrm{mg} / \mathrm{kg}$ BW (15 days),

A3: Treated $100 \mathrm{mg} / \mathrm{kg}$ BW (15 days),

B1: Control (30 days),

B2: Treated $50 \mathrm{mg} / \mathrm{kg}$ BW (30 days),

B3: Treated $100 \mathrm{mg} / \mathrm{kg}$ BW (30 days)

A: Antrum; FC: Follicular cells; C: Corpus luteum; CR: Corona radiata; DGF: De Graaf's follicle; PF: Primary follicle; PmF: primordial follicle; SF: Secondary follicle; TF: tertiary follicle; O: Oocyte; DF: Dehiscent follicle; OS: Ovarian stroma; ET: External theca; IT: Internal theca; BV: Blood vessel 
Table 1: Effect of Cnestis ferruginea on ovarian organelles after 15 (set I) and 30 (set II) days of treatment.

\begin{tabular}{|c|c|c|c|c|c|c|}
\hline \multirow{2}{*}{ Follicle } & \multicolumn{3}{|c|}{15 Days } & \multicolumn{3}{|c|}{30 Days } \\
\hline & Control & $\mathrm{AECF}_{50}$ & $\mathrm{AECF}_{100}$ & Control & $\mathbf{A E C F}_{50}$ & $\mathrm{AECF}_{100}$ \\
\hline corpus luteum & $8,33 \pm 0,56$ & $11,33 \pm 1,09$ & $12,17 \pm 0,95^{*}$ & $9,67 \pm 0,96$ & $14,67 \pm 1,33^{*}$ & $14,17 \pm 1,30^{*}$ \\
\hline De Graaf's follicles & $2,33 \pm 0,42$ & $5,16 \pm 0,87^{*}$ & $6,17 \pm 0,83^{* *}$ & $3,17 \pm 0,70$ & $6,67 \pm 0,99^{*}$ & $7,83 \pm 0,87^{* *}$ \\
\hline tertiary follicles & $2,67 \pm 0,56$ & $5,50 \pm 0,87$ & $6,17 \pm 0,89^{*}$ & $3,33 \pm 0,72$ & $6,50 \pm 0,89 *$ & $7,17 \pm 0,87^{*}$ \\
\hline Secondary follicles & $4,16 \pm 0,60$ & $7,33 \pm 0,76^{*}$ & $7,50 \pm 0,85^{*}$ & $4,83 \pm 0,95$ & $8,83 \pm 0,87^{*}$ & $8,33 \pm 0,76^{*}$ \\
\hline Other follicles & $24,83 \pm 1,91$ & $26,67 \pm 2,11$ & $29,50 \pm 1,86$ & $23,17 \pm 1,96$ & $28,33 \pm 1,63$ & $31,50 \pm 2,90^{*}$ \\
\hline
\end{tabular}

Note: Values are means $\pm \operatorname{SEM}(n=6) ;{ }^{*}=\mathrm{p}<0.05 ;{ }^{* *}=\mathrm{p}<0.01$. Control: Distilled water, $\mathrm{AECF}_{50}$ : Aqueous Extract of $C$. freruginea $(50 \mathrm{mg} /$ $\mathrm{kg}$ of body weight), $\mathrm{AECF}_{100}$ : Aqueous Extract of $\mathrm{C}$. freruginea $(100 \mathrm{mg} / \mathrm{kg}$ of body weight).

Histological study of rats ovaries treated for 15 days (set I) and 30 days (set II) with the aqueous extract of $C$. ferruginea and the vehicle was carried out (Figure 1) and the results are recorded in the (Table 1). Indeed, animals treated for 15 days with $\mathrm{AECF}_{100}$ showed significant increase $(\mathrm{p}<0.05)$ of corpus luteum number of $46.05 \%$ compared to controls while the increase induced by the low dose is not significant. With the 30-day duration, treatments using $\mathrm{AECF}_{50}$ and $\mathrm{AECF}_{100}$ resulted in a significant $(\mathrm{p}<0.05)$ increase in corpus luteum number of $51.75 \%$ and $46.58 \%$, respectively, compared with controls. Counting of De Graaf follicle showed a significant $(p<0.05)$ increase in its number with $\mathrm{AECF}_{50}$ for both treatment durations. The results made it possible to record a rate of increase of $121.47 \%$ and $110.51 \%$ respectively for the 15 and 30 day treatment periods. As for $\mathrm{AECF}_{100}$, the results showed a very significant increase (P $<0.01$ ) of these follicles compared with controls. Thus, a rate of $164.34 \%$ and $147.33 \%$ increase was recorded respectively for the 15 and 30 day treatment durations. The 15-day treatment with
$\mathrm{AECF}_{100}$ resulted in a significant $(\mathrm{p}<0.05)$ increase of $131.23 \%$ in the number of tertiary follicles compared with controls.

The increase induced by the dose of $50 \mathrm{mg} / \mathrm{kg}$ of BW is not statistically significant ( $p>0.05$ ). With the 30-day treatment, there was a significant increase ( $p<0.05$ ) of $95.02 \%$ and $115.03 \%$ respectively for $\mathrm{AECF}_{50}$ and $\mathrm{AECF}_{100}$. Regarding the secondary follicles, the extract induced a significant increase $(p<0.05)$ in its number regardless of the dose and duration of treatment. Thus, there is an increase of $75.98 \%$ and $77.99 \%$ respectively with $\mathrm{AECF}_{50}$ and $\mathrm{AECF}_{100}$ for the duration treatment 15 days. With respect to the 30 -day treatment duration, the increase is $82.76 \%$ with the two doses used. The number of primary follicles and primordial follicles grouped under the name of other follicles, did not show a significant increase $(p>0.05)$ of its number with the treatment of duration 30 days at the dose of $100 \mathrm{mg} / \mathrm{kg}$ of $\mathrm{BW}\left(\mathrm{AECF}_{100}\right)$. This increase is $63.25 \%$ compared to controls. Any other observed increase in these follicles is not statistically significant ( $p>0.05$ ).

\section{Effects of the Extract on the Histological Structure of the Uterine Horns}

Table 2: Effect of Cnestis ferruginea on the histological structure of the uterine horns of rats after 15 and 30 days of treatment.

\begin{tabular}{|c|c|c|c|c|c|c|}
\hline \multirow{2}{*}{ Uterine parameters } & \multicolumn{3}{|c|}{15 Days } & & \multicolumn{2}{|c|}{30 Days } \\
\cline { 2 - 6 } & Control & AECF $_{50}$ & AECF $_{100}$ & Control & AECF $_{50}$ & AECF $_{100}$ \\
\hline $\begin{array}{c}\text { lumen diameter of } \\
\text { uterine horn }(\mu \mathrm{m})\end{array}$ & $498,70 \pm 37,74$ & $658.40 \pm 69,31^{*}$ & $694,57 \pm 13^{*}$ & $535,50 \pm 41,91$ & $763,60 \pm 78,13^{*}$ & $815,10 \pm 57,63^{*}$ \\
\hline $\begin{array}{c}\text { Thickness of } \\
\text { endometrium }(\mu \mathrm{m})\end{array}$ & $388,30 \pm 57,24$ & $528,40 \pm 36,67$ & $664,80 \pm 43,65^{*}$ & $464,80 \pm 36,04$ & $724,40 \pm 39,76^{*}$ & $669,40 \pm 77,25^{*}$ \\
\hline $\begin{array}{c}\text { Height of epithelial } \\
\text { cells }(\mu \mathrm{m})\end{array}$ & $18,04 \pm 1,05$ & $23,35 \pm 0,62$ & $26.76 \pm 1,49^{*}$ & $17,24 \pm 0,82$ & $26,21 \pm 3,14^{*}$ & $26,84 \pm 1,83^{*}$ \\
\hline $\begin{array}{c}\text { Number of uterine } \\
\text { glands }(\mu \mathrm{m})\end{array}$ & $23,43 \pm 3,46$ & $24,69 \pm 0,73$ & $25,12 \pm 2,36$ & $26,33 \pm 2,39$ & $29,00 \pm 1,86$ & $36,83 \pm 3,70^{*}$ \\
\hline $\begin{array}{c}\text { Diameter of uterine } \\
\text { glands }(\mu \mathrm{m})\end{array}$ & $38,01 \pm 2,13$ & $55,64 \pm 1,64^{*}$ & $54,98 \pm 2,64^{*}$ & $37,17 \pm 4,01$ & $60,34 \pm 2,73^{*}$ & $64,84 \pm 7,49^{* *}$ \\
\hline
\end{tabular}

Note: Values are means $\pm \operatorname{SEM}(n=6) ;{ }^{*}=p<0.05 ;{ }^{* *}=p<0.01$. Control: Distilled water, $\mathrm{AECF}_{50}$ : Aqueous Extract of $\mathrm{C}$. freruginea (50mg/kg of body weight), $\mathrm{AECF}_{100}$ : Aqueous Extract of $C$. freruginea (100mg/kg of body weight).

Histological studies performed on the uterine horn (Figure 2) showed a significant increase $(\mathrm{p}<0.05)$ in the lumen diameter of this organ regardless of the duration of treatment and the dose of the extract administered. Indeed, the treatment of duration 15 days showed an increase of $32.02 \%$ and $39.28 \%$ respectively for
$\mathrm{AECF}_{50}$ and the $\mathrm{AECF}_{100}$. The results also showed a rate of increase of $42.60 \%$ and $52.21 \%$ respectively for $\mathrm{AECF}_{50}$ and $\mathrm{AECF}_{100}$ after 30 days of treatment. At the endometrial level, the extract at the dose of $100 \mathrm{mg} / \mathrm{kg}$ BW $\left(\mathrm{AECF}_{100}\right)$ caused a significant increase $(\mathrm{p}<0.05)$ in its thickness after 15 days of treatment. This increase is $71.21 \%$ 
compared to controls. After 30 days of treatment, this tissue has grown significantly ( $\mathrm{p}<0.05$ ) by $55.85 \%$ and $44.01 \%$ respectively with $\mathrm{AECF}_{50}$ and $\mathrm{AECF}_{100}$ compared to controls. The increase in endometrial thickness induced by $\mathrm{AECF}_{50}$ is not significant.
Concerning epithelial cells, the extract showed a significant ( $p$ $<0.05$ ) increase of $48.32 \%$ in height after 15 days of treatment with EACF100. While the increase induced by the $\mathrm{EACF}_{50}$ is not significant.
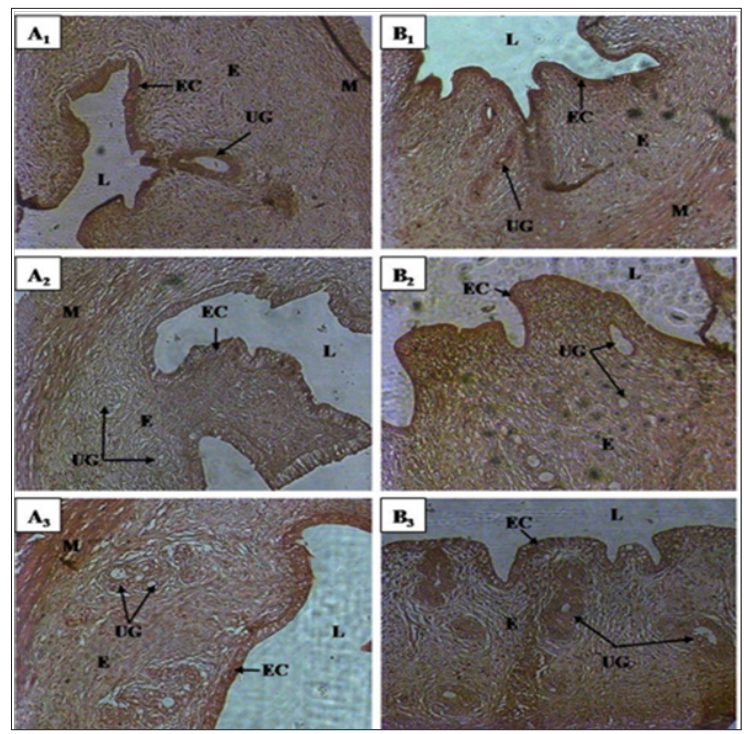

Figure 2: Uterine horn micrographs of control and treated rats with Cnestis ferruginea at 15 and 30 days

A1: Contol (15 days);

A2: Treated $50 \mathrm{mg} / \mathrm{kg} \mathrm{BW}$ (15 days);

A3: Treated $100 \mathrm{mg} / \mathrm{kg} \mathrm{BW} \mathrm{(15} \mathrm{days)}$

B1: Control (30 days);

B2: Treated $50 \mathrm{mg} / \mathrm{kg}$ BW (30 days);

B3: Treated $100 \mathrm{mg} / \mathrm{kg}$ BW (30 days)

EC: Epithelial cells; E: Endometrial; UG: Uterine gland; L: Lumen; M: Myometrium.

At the end of 30 days of treatment, the results showed a significant $(\mathrm{p}<0.05)$ increase of $44.02 \%$ and $55.68 \%$ respectively with $\mathrm{AECF}_{50}$ and $\mathrm{AECF}_{100}$ of epithelial cell height compared to controls. The number of uterine glands did not increase significantly $(\mathrm{p}<0.05)$ after 30 days of treatment with AECF100. All other increases are not statistically significant ( $p>0.05$ ). It should be noted that with the 30-day treatment, the results showed a beginning of necrosis of the uterine glands and epithelial cells in $50 \%$ of the rats treated with $\mathrm{EACF}_{100}$. In this study, measurement of uterine gland diameters showed that all doses administered increased significantly regardless of the duration of treatment. Thus, after 15 days of treatment there was an increase of $46.38 \%$ ( $p<0.05$ ) and 44.64\% ( $p<0.05$ ) compared to controls. After 30 days of treatment, rates of $62.34 \%(p<0.05)$ and $74.44 \%(p<0.01)$ increase relative to the controls (Table 2) are obtained.

\section{Discussion}

The results obtained on the structure of the ovaries indicate that the extract of $C$. ferruginea induces a significant increase in the number of corpus luteum. The corpus luteum being a product of ovulation, increase of these shows an inducing effect of ovulation by the plant extract. These results corroborate those of administration of extract mixture of Medicago sativa (Fabaceae) and Salvia officinalis (Lamiaceae) to female mice [5]. These results are contrary to those obtained by Kouakou [6]. Indeed, this author administered extracts of Daldinia concentrica (Xylariaceae) and Psathyrella efflurescens (Coprinaceae) to rats and recorded a significant reduction in the number of corpus luteum. These results could be an effect of the extract at the central level by stimulating the release of LH whose peak corresponds to ovulation. It is established that ovulation is comparable to an inflammatory process [7]. Thus, the extract appears to stimulate the activation of the genes involved in the prostaglandin and leukotriene synthesis cascade to induce ovulation. Otherwise, studies by Lim et al. [8] found that cyclooxygenase-deficient (COX-2) mice suffer from defects in reproductive functions such as ovulation and fertilization. Indeed, this enzyme is very important in ovulation because of its essential role in follicular rupture. The extract may exert an activating effect on COX-2 or stimulate its production to induce ovulation and in turn the increase in the number of corpus luteum.

The effect of the extract is not limited only to the induction of ovulation. It extends to all folliculogenesis. Indeed, folliculogenesis according to Monget et al. [7] occurs in two phases: the regulation 
of the first phase (basal phase) that extends from the primordial follicle to the tertiary follicle is intra-ovarian and the second phase of the tertiary follicle to ovulation is entirely dependent on the gonadotropins. According to Vaissaire [9], the growing follicles exert an inhibition on the exit of the new follicle. Thus, during the first phase, the extract could stimulate the follicle recruitment by lifting this inhibition somewhat. This would explain the increase in the number of primordial, primary, and tertiary follicles found in this study. Concerning De Graaf follicles in the second phase of folliculogenesis, its increase in this study could be explained by a central action of the extract to stimulate the release of FSH. In addition, the extract could activate IGF-I which is a growth factor and plays a key role in the transition from basal folliculogenesis to gonadotropin-dependent folliculogenesis. This result also confirms the high number of corpus luteum recorded in this study.

Histological studies performed during this experiment showed a significant increase in uterine horn diameter, endometrial thickness, height of epithelial cells, uterine gland diameter, and uterine gland number in rats treated with the plant extract compared to the controls group. Similar results were obtained by Bleu et al. [10] after the administration of aqueous extract of Passiflora. Foetida and $17 \beta$-oestradiol to ovariectomized immature rats. Concerning the height of the epithelial cells and the diameter of the uterine glands, these results are similar to those of Adaay and Mosa [11]. Indeed, these authors administered the aqueous extract of Tribulus terrestris (Zygophyllaceae) to the mice and obtained a significant increase in these parameters.

Otherwise, the increase in the above-mentioned parameters completed by the onset of necrosis of the uterine glands and epithelial cells observed accurately reflects the characteristic manifestation of estrus at the structural level of the uterus in the rat. Indeed, Westwood [12] studying the structures of the organs of the reproductive tract according to the stages of the estrus cycle in the rat has been able to establish that the estrus is marked in the uterus by a degeneration of the uterine glands, followed by the epithelial cells.

This is accompanied by a loss of mitotic activity and infiltration of leucocytes. The dilation of light may persist until the end of estrus, although this is not usually the case. In addition, the increase in endometrial thickness in this study may be related to stimulation of mitotic activity in the endometrium induced by the plant extract. Indeed, Westwood [12] reported a recovery of mitotic activity towards the end of estrus. This activity could be stimulated rather by the extract to amplify the mitotic activities induced during the proestrus phase [13,14]. Regarding epithelial cells, Soto et al. [15] reported that systemic and local IGF-I plays an important role in the effect of estrogen on the growth and epithelial proliferation of the mouse uterus. The extract of $C$. ferruginea could stimulate the production of IGF-I and induce the effects observed in the treated rats. It should be noted that any cellular proliferative activity that takes place in the uterus of rodents depends on a direct action of estrogen [16]. The extract could directly stimulate cell proliferation by having it as an estrogen-like one or by stimulating the release of estradiol. Ultimately, the aqueous extract of Cnestis ferruginea induced stimulation of folliculogenesis by increasing the number of follicles at different stages of evolution. This plant extract also induces ovulation. On the uterus, C. ferruginea causes the manifestation of estrus and behaves like endogenous estrogen.

\section{Acknowledgement}

The authors are indebted to Dr. Mangué N'Tapké Emmanuel Jaurès (Director of the Laboratory of Endocrinology and Reproductive Biology) to have available all the necessary equipment for this work.

\section{References}

1. Verlet N (1990) New markets for herbs in France andEurope. Herb Spice Med Pl Digest 8: 1-5.

2. Balandrin MF, Kinghorn AD, Farnsworth NR (1993) Plant-derived natural products in drug discovery and development-an overview. In Human medicinal agents from plants. (Eds.) AD Kinghorn and MF Balandrin Am Chem Soc, San Francisco, Canada, p. 2-12.

3. Tra Bi FH (1997) Utilisation des plantes, par l'homme, dans les forêts classées du Haut-Sassandra et de Scio, en Côte d'Ivoire. Thèse de doctorat 3e cycle, Université d'Abidjan Cocody, pp. 215.

4. N'guessan K, Kouadio K, Kouamé NF (2006) Plantes emménagogues utilisées en médecine traditionnelle par les peuples Abbey et Krobou d'Agboville (côte d'ivoire). Parm Méd Afr 14: 137-158.

5. Adaay MH, Al-Dujaily SS, Ferial K, Khazzal FK (2013) Effect of aqueous extract of Medicago sativa and Salvia officinalis mixture on hormonal, ovarian and uterine parameters in mature female mice. J Mater Environ Sci 4(4): 424-433.

6. Kouakou K (2000) Etude des effets antifertilisants de l'extrait de deux champignons (Daldinia concentrica, Bolt. 1863 et Psathyrella efflorescens, Berk, 1977) de la pharmacopée ivoirienne chez la ratte. Thèse de Doctorat 3ème cycle, Université de Cocody-Abidjan, pp.122.

7. Monget P, Hembert S, Binart N, Gougeon A, Panthier JJ (1999) La physiologie ovarienne: ce que nous disent les souris. Med Sci (Paris) 15(2) : 141-147.

8. Lim H, Paria BC, Das SK, Dinchuk JE, Langenbach R, et al. (1997) Multiple female reproductive failures in cyclooxygenase 2-deficient mice. Cell 91(2): 197-208.

9. Vaissaire JP (1977) Sexualité et Reproduction des mammifères domestiques et de laboratoire. Paris Maloine Editeur 457.

10. Bleu GM, Kouakou K, Zahoui OS, Touré A, Traoré F (2012) Oral acute toxicity and estrogenic effects of the extracts of Passiflora foetida Linn. (Passifloraceae) leaves in female Wistar albino rats. Ann Biol Res, 3(9): 4609-4616.

11. Adaay MH, Mosa AR (2012) Evolution of the effect of aqueous extract of Tribulus terrestris on some reproductive parameter in mice. J Mater Environ Sci 3(6): 1153-1162.

12. Westwood FR (2008) The female rat reproductive cycle: a practical histological guide to staging. Toxicol Pathol 36(3): 375-384.

13. Wheater PR, Burkitt GH, Daniels VG, Deakin JP (1979) Histologie fonctionnelle. Ed Medécine et sciences Internationales (MEDSI) 278.

14. Russell WF (2008) The female reproductive cycle: a pratical histological Guide to standing. Toxicol Pathol 36(3): 375-384.

15. Soto M, Maeba H, Watari J Takashio M (2002) Analysis of an inactivated Lg-FL01 gene present in bottom-fermeting yeast. J Biosci Bioeng 93(4): 395-398.

16. Tong W, Pollard JW (2002) In The endometrium. Glasser SR, Aplin JD, Giudice LC, Tabibzadeh S, (Eds.) Taylor and Francis, London, pp. 94-109. 


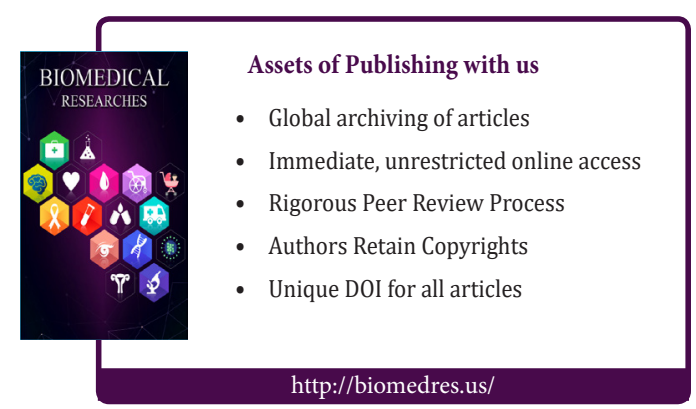

